\title{
New taxa of Middle Jurassic gastropods from Kachchh (western India) in the collections of the Banaras Hindu University (Varanasi, India)
}

\author{
JÁNOS SZABÓ $^{1} \&$ ANAND KUMAR JAITLY ${ }^{2}$ \\ ${ }^{1}$ Hungarian Natural History Museum, Department of Palaeontology and Geology, \\ Ludovika tér 2., H-1083 Budapest, Hungary \\ E-mail:szabo.janos@nhmus.hu \\ 2 Banaras Hindu University, Department of Geology, Varanasi-221005, India \\ E-mail:akjaitly@gmail.com
}

\begin{abstract}
A new genus and six new species are introduced in this paper; they are: Jumaramaria jumaraensis n. gen. \& n. sp. (Pleurotomariidae), Solarioconulus kachchhensis n. sp. (Ataphridae), Chartronella belaensis n. sp. (Paraturbinidae), Planiturbo lerensis n. sp. (Metriomphalidae), Exelissa indiana n. sp. (Cryptaulacidae), and Sulcoactaeon? haboensis n. sp. (Aplustridae). With 49 figures.
\end{abstract}

Key words - Middle Jurassic, India, Kachchh, Gastropoda, Jumaramaria

\section{INTRODUCTION}

Disregarding some minor changes, the content of this paper was published electronically in the volume 36 of Fragmenta Palaeontologica Hungarica (SzaBó \& JAITLY 2019, p. 3-30.). Normally that journal had also printed volumes, thereforethemanuscriptwasprepared for thatsituation. However, technicaltroubles arisen that disallowed the printing, so the new taxa of the original paper remained invalid under the rules of the INTERNATIONAL COMMISSION OF ZOOLOGICAL Nomenclature (1999). Subsequenly, publishing of the journal has become uncertain in both forms, and the descriptions of new taxa of the mentioned paper need to be placed in another journal, in which publishing seems guaranteed. The original paper, containing additional information about the Kachch material, is accessible electronically in the website of the Hungarian Natural History Museum: http://publication.nhmus.hu/pdf/fragpal/Fragm_paleont_hung_2016_Vol_36_3.pdf 


\section{LOCALITIES, MATERIAL AND METHODS}

The first paper on this collection (JAITLY et al. 2000) and its references provide detailed information about the geological settings and geographic position of the localities.

A part of the gastropods, discussed in this paper, are from the considerable number of specimens, which have been separated formerly as not or hardly identifiable owing to various reasons such as missing critical shell parts, deformation, risky for cleaning, etc. Another group of the specimens were collected during subsequent fieldworks.

The types and other figured specimens are deposited in the Invertebrate Palaeontology Laboratory, Department of Geology, Banaras Hindu University, Varanasi, India; in short form: BHU.

Figures were prepared using ammonium-chloride coating on the specimens, and the focus stacking method to reach higher quality of them by Helicon Focus Pro 6.8.0 software (https://www.heliconsoft.com).

Abbreviations for the measurements: $\mathrm{H}=$ full height; $\mathrm{HL}=$ height of last whorl; $\mathrm{HP}=$ height of peristome; $\mathrm{D}=$ maximal diameter of shell; $\mathrm{W}=$ width of peristome. Another abbreviation, used in the paper is "dam." to indicate that the given measurements have been taken on damaged shell along the standard lines without reconstruction.

In this paper, the descriptions follow the terminological proposals by KNIGHT et al. (1960) with some slight modifications.

\section{SYSTEMATIC PALEONTOLOGY}

Class Gastropoda Cuvier, 1795

Subclass Archaeogastropoda Thiele, 1925

Order Vetigastropoda Salvini-Plawen, 1980

Superfamily Pleurotomarioidea Swainson, 1840

Family PLEUROTOMARIIDAE Swainson, 1840

Genus Jumaramaria n. gen.

Type species - Jumaramaria jumaraensis n. sp.

Derivation of name - Composed of the locality name, Jumara Dome and maria (Latin) = seas, common second part of names amongst slit-bearing Vetigastropods.

Diagnosis - Low spired, broadly phaneromphalous, rather rapidly expanding shell with convex whorls. Early whorls evenly arched but last whorl subangular since feebly concave outer face formed below selenizone. Transition to convex base widely rounded angular. Selenizone flush on early teleoconch then increasingly 
convex. Peristome and aperture nearly radial with abaperturally concave umbilical lip, having narrow, flat frontal face. Shallow collabral undulation visible on base. Whole surface ornamented by spiral threads. Growth lines parasigmoidal and orthocline or just prosocline between upper suture and selenizone; prosocyrt between selenizone and periphery; markedly prosocline, straight or shallowly parasigmoidal between periphery and umbilicus.

Remarks - In general, Jumaramaria differs from the pleurotomariid genera in formation of the growth lines, which more or less indicate also the shape of the peristome that is incompletely preserved on the available specimen. Jumaramaria has parasigmoidal, orthocline or barely prosocline growth lines between the upper suture and the selenizone while other genera of the family have prosoclineprosocyrt growth lines in this area. At the same time, the basal growth lines are strongly prosocline and straight or feebly parasigmoidal in Jumaramaria but usually markedly parasigmoidal, frequently sickle-shaped, and moderately prosocline in doubtless pleurotomariids.

The shape of Jumaramaria shows some similarity to conoidal, non-gradate, low or medium high spired genera of Pleurotomariidae like Perotrochus or Mikadotrochus. In both genera, the shape is trochiform, the selenizone is flush, and the angulation with outer face is lacking from the last whorl besides the differences in the growth line form and orientation. In the presence of the rudimentary angulation and outer face on the last whorl, some Laevitomaria species may be similar but the form and orientation of the growth lines distinguish them. In Bathrotomaria, the angulation with coinciding selenizone is not restricted to the last whorl but already develop in the early teleoconch. Similarly, some Obornella species may have comparable shape but their peripheral carina or swollen belt at the rim of the base distinguish them.

Distribution - Kachchh, India, Bathonian.

Jumaramaria jumaraensis n. sp.

(Figures 1-6.)

Type specimen - Holotype Inv. № BHU2020I 1.

Type locality - Jumara Dome, Kachchh, western India.

Type strata - Jhurio Formation, Bathonian.

Derivation of name - From Jumara Dome.

Diagnosis - Same as for the genus above.

Material - Single, multiadamaged shell.

Measurements $-\mathrm{H} \mathrm{dam} .=27 \mathrm{~mm}, \mathrm{HL}=21.6 \mathrm{~mm}, \mathrm{HP}=15.3 \mathrm{~mm}, \mathrm{D}=43 \mathrm{~mm}$, $\mathrm{W}$ dam. $=23.5 \mathrm{~mm}$, pleural angle: $113^{\circ}$.

Description - The available specimen has a rather low turbiniform, rapidly expanding shell of convex whorls, which have no angulation between the pairs of sutures on the early teleoconch. Last whorl joins to the base through a widely 
rounded angulation that is followed by the suture on former whorls. On the last whorl, the area between the selenizone and the rim of the base becomes slightly concave so a narrow, obscure outer face develops in the latest growth phases. The selenizone itself runs below the mid-whorl; it is rather wide along the whole shell. Its surface is flat on the early teleoconch then changes into convex. The suture is impressed and it is accompanied abapically by an upward bent, narrow belt of the shell, which causes a shallow, subsutural concavity of the whorl surface. The base is flattened as a whole with a moderately convex wall, and has a broad umbilicus. Rim of the umbilicus is also widely rounded angular. The peristome is incompletely preserved but the remnants indicate an abaxially elongated aperture that is almost in radial position as the form of the growth lines suggests it. Its parietal lip appears as the edge of a thin shell enamel; the umbilical lip is slightly thickened and backward oriented from the parietal wall towards the basal lip; it has also a narrow outer face and a wide, shallow sinus between the parietal and basal lip.

Spiral ornament of the shell consists of threads on the whole surface of the shell, including also the selenizone. On the last whorl, the selenizone bears three threads beside its edges, which appear also as threads where not damaged. These spiral threads are nearly equally strong almost everywhere, except the subsutural area where thinner and stronger threads alternate. Much thinner and somewhat denser threads cross the spiral ones collabrally on the whorls and form together a characteristic network. In the basal region, only differently strong growth threads and striae cross irregularly the spiral threads. Shallow, collabral surface undulation is also observable on the base; it is clearer in the parietal region.

The growth lines are orthocline or just barely prosocline, and slightly parasigmoidal between the adapical suture and the selenizone, orthocline and strongly prosocyrt between the selenizone and the obscure angulation at the abaxial rim of the base; strongly prosocline and almost straight or barely parasigmoidal on the base.

Remarks - No other species, fitting with the description of the genus has been found.

Occurence - Jumara Dome, Jhurio Fm., Bathonian.

Superfamily Ataphroidea Cox, 1960

Family ATAPHRIDAE Cox, 1960

Genus Solarioconulus Cossmann, 1918

Type species - Trochus nudus Münster, 1841 


\section{Solarioconulus kachchhensis n. sp.}

(Figures 7-11.)

Type specimen - Holotype Inv. №: BHU2020I 2.

Type locality - Habo Dome, Kachchh, western India.

Type strata - Chari Formation, Callovian.

Derivation of name - From name of the larger locality area.

Diagnosis - Turbiniform shell with low protoconch and convex whorls. Suture impressed and abapically accompanied by belt of concavity, widening on last whorl as narrow ramp with indistinct outer rim. Last whorl slightly expanding and downward turning. Base convex, phaneromphalous. Peristome strongly prosocline, interrupted at suture, thin in parietal region and reflecting over umbilicus.

Material - Single shell with dense traces of ramifying borings on latest whorls.

Measurements - Inv. № BHU2020I $2 \mathrm{H}=17.7 \mathrm{~mm}, \mathrm{HL}=14 \mathrm{~mm}$, $\mathrm{HP}=9.8 \mathrm{~mm}, \mathrm{D}=16.4 \mathrm{~mm}, \mathrm{~W}=9 \mathrm{~mm}$, apical angle: $93^{\circ}$, pleural angle: $82^{\circ}$.

Description - A turbiniform shell is available that has blunt apex, moderately convex whorls and a convex base. The initial chamber of the protoconch just feebly rises above the first, almost planispiral whorl then the coiling rapidly changes into clearly trochospiral. Teleoconch whorls are initially almost flat then increasingly convex; from the penultimate whorl, a narrow and shallow concave belt is formed subsuturally; the suture is slightly impressed. Base as a whole and also its wall are convex with arched transition towards the outer whorl surface; a narrow umbilicus with rounded rim is present. Near the peristome, the last whorl slightly deviates downward, and the subsutural concave belt widens as a ramp without distinct abaxial rim. The peristome is suborbicular, prosocline and tangentially joins to the last whorl. Its parietal lip appears as thin callosity, the other parts are rather thick but outward tapering. The umbilical lip and the adaxial part of the basal lip form a narrow, lunuliform and feebly concave outer face.

The shell is smooth, some marked collabral ridges appear only near the peristome but they may have been grown during reparation of a shell damage. The growth lines are very fine, like in other ataphrids; actually, some pieces are observable only partly owing to a dense network of a shallow boring system on the surface of the shell.

Remarks - Morphology of the available specimen well matches with the diagnosis of Solarioconulus Cossmann, 1918. The main difference from the type species is that it has acute, feebly coeloconoidal early whorls, which are simply conoidal in the Kachchh species. The shell is very similar also to Buckmanina Cossmann, 1920 but the thickened peristome, which is continuous also at the parietal part, distinguishes it. The morphology of these genera is close to those of some ataphrid genera, which explains the opinion about the family attribution.

Occurrence - Habo Dome, Chari Formation, Callovian. 
Superfamily Trochoidea Rafinesque, 1815

Family PARATURBINIDAE Cossmann, 1916

Genus Chartronella Cossmann, 1902

Type species - Chartronia digoniata Cossmann, 1902

Chartronella belaensis n. sp.

(Figures 12-16.)

Type specimen - Holotype Inv. № BHU2020I 3.

Type locality - Bela Island, Kachchh, western India.

Type strata - Chari Formation, Callovian.

Name - From the name of the type locality.

Diagnosis - Low spired shell of rapidly expanding whorls. Suture deeply impressed. Last whorl tri-carinated with markedly concave interspaces. Lowermost carina hidden on former whorls under suture in deep furrow. Last whorl downward deviating near final peristome, being strongly prosocline and slightly thickened.

Material - Single, fragmentary, and strongly worn specimen; a part of the peristome and large connected parts are lacking from the base.

Measurements - Inv. №: BHU2020I 3: $\mathrm{H}$ dam. $=5.5 \mathrm{~mm}, \mathrm{D}$ dam. $=8.8 \mathrm{~mm}$, pleural angle: $102^{\circ}$

Description - The specimen on hand represents a low spired species with a tricarinate last whorl and a strongly convex, anomphalous base, having slightly convex wall. Between pairs of the carinae, deep, concave belts are formed. The lowermost carina is overlapped on the spire whorls by the suture and the accompanying uppermost carina. The suture itself seems rather deeply impressed. The adapical concave belt widened and the last whorl considerably deviated abapically in the last growth phase so the latest peristome became extremely prosocline. The remnants indicate its subcircular shape; the preserved parietal and basal peristome parts are slightly thickened internally.

A small area of the outer face on the last whorl preserved the ornament of very thin, rather sparse spiral threads.

Figures 1-16. Species of Vetigastropoda 1. 1-6=Jumaramaria jumaraensis n. gen. n. sp. holotype in apical (1), basal (2), abapertural (3), and apertural (4) views, $\times 1.4$; (5) details of the ramp at higher magnification, $\times 2.5$; (6) details of the selenizone ornament, $\times 4.4 .7-11=$ Solarioconulus kachchhensis $\mathrm{n}$. sp. holotype in abapertural (7), apical (8), apertural (9) and basal (10) views, $\times 2$; magnified view of a boring system from the last whorl, $\times 3.12-16=$ Chartronella belaensis $n$. sp. holotype in abapertural (12), apertural (13), apical (14) and basal (15) views, $\times 3.4 ;(16)$ details of shell part with spiral ornament remnants, $\times 11$. 

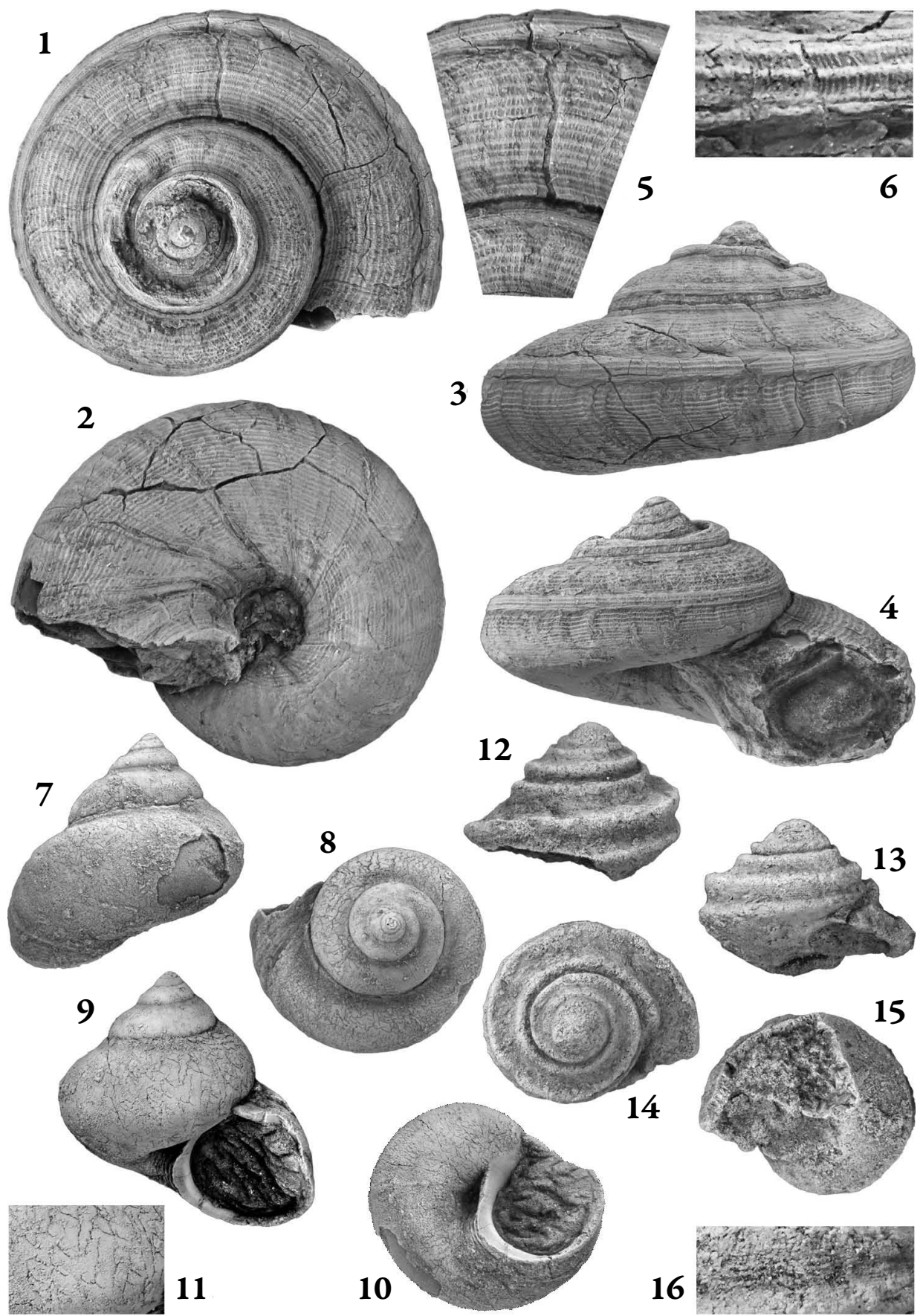
Remarks - In spite of the poor preservation, the specimen well shows some characters, which distinguish it from the formerly published Chartronella species. The Bathonian Trochus obtusus Rigaux \& Sauvage, 1869 is the most similar to the Kachchh specimen. It has also a rather low spire, comparable size, a blunt apical region and an ornament of delicate spiral threads, however, the interspaces between pairs of the carinae are much less concave; the carinae themselves are much weaker than in Chartronella belaensis n. sp.

Occurrence - Bela Island, Chari Formation, Callovian.

Family METRIOMPHALIDAE Gründel, Keupp \& Lang, 2017

Genus Planiturbo J.-C. Fischer, 1969

Type species - Turbo planispira Cossann, 1885

Planiturbo lerensis n. sp.

(Figures 17-28.)

Type specimens - Holotype Inv. № BHU2020I 4; paratype: Inv. № BHU2020I 5.

Type locality - Near Ler, Kachchh, western India.

Type strata - Upper Chari Formation, Callovian.

Name - From the name of village Ler.

Diagnosis - Shells of about five dextral whorls, initial ones discoidally coiled, resulting concave apex. Trochospiral coiling started from third whorl with convexly arched surface. Base slightly less convex than last whorl, transition between them widely arched. Moderately broad umbilicus with angular basal rim present. Aperture suborbicular, peristome continuous with thick parietal part. Ornament of several subequally spaced, strong, nodulose carinae, starting from third whorl. Transverse ornament of collabral riblets between pairs of carinae. Growth lines appearing like thin threads.

Material - Two multi-damaged specimens; the shell remnants are strongly fragmented on the surface of porous infilling sediment; their further cleaning would be too risky.

Measurements - Inv. № BHU2020I $4 \mathrm{H}$ dam. $=9.6 \mathrm{~mm}, \mathrm{D}$ dam. $=10.8 \mathrm{~mm}$. Inv. № BHU2020I $5 \mathrm{H}$ dam. $=9.3 \mathrm{~mm}, \mathrm{D}$ dam. $=10.7 \mathrm{~mm}$.

Description - Shells consist of 4.5 to 5 whorls; the earliest 2.5 to 3 ones are coiled in dextral discoidal way so they form broad, slightly concave apical area. In this shell region the whorls are flat and sharply angular along the abaxial suture; the suture itself is flush here. From the third whorl, the coiling gradually alters into trochospiral; the abaxial angulation becomes increasingly rounded then the whole whorl surface changes into convexly arched. The last whorl turns into 
the less convex base through a rather wide arch. A rather broad umbilicus with angular rim and almost cylindrical inner wall is observed in both specimens. From the peristome, only the parietal lip is preserved; it consists of a thick, smooth shell layer and a part of an inner, possibly circular, thickening along the basal edge. The shell remnants are indicative of a suborbicular aperture and a prosocline, entire peristome with wide "V"-shaped inner lip and largely arched outer lip with tubular nodules or spines as terminal processes of the carinae.
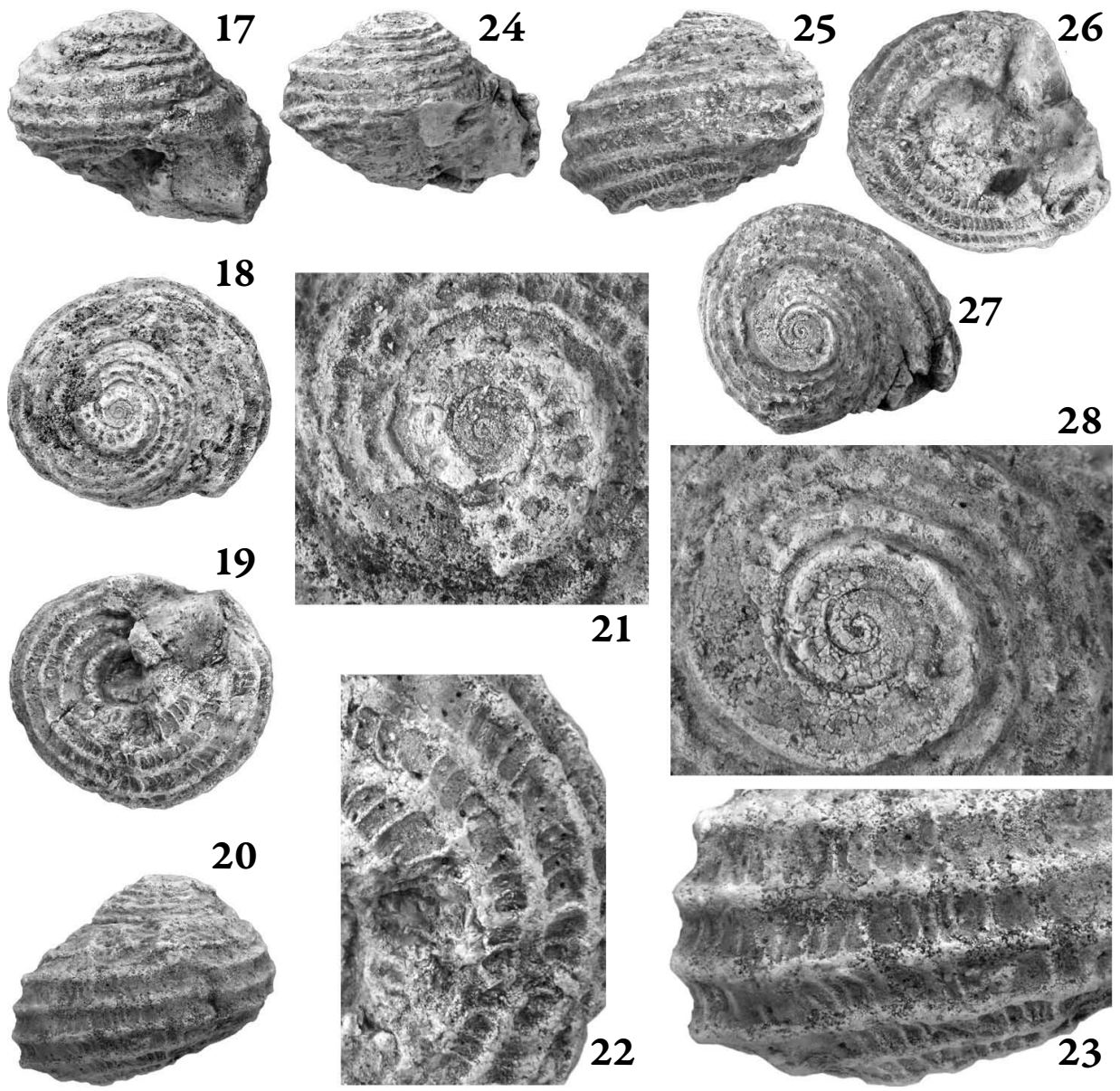

Figures 17-28. Species of Vetigastropoda 2. 17-23 = Planiturbo lerensis n. sp., holotype in apertural (17), apical (18), basal (19), and abapertural (20) views, $\times 2.8$; details of the early shell (21), $\times 9$; details of the basal ornament (22), $\times 7.6$; details of the last whorl ornament $(23), \times 7$. 24-28 = Planiturbo lerensis n. sp., paratype in abapertural (24), apertural (25), basal (26), and apical (27) views ( $\times 2.8)$, details of the earliest whorls $(28), \times 10.3$. 
From the terminal half of the second coil, single swollen spiral belts start along both sutures, which have been formerly flush. Soon spirally elongate nodules appear on these swellings. From the third whorl, the swollen belts become nodosed carinae. Between them, subregularly repeated, sparse, feebly prosocline, collabral ribs develop. From the fourth whorl a third carina also appears halfway between the former ones then the number of carinae gradually increases to 5 or 6 for the last growth phase. In addition, four similar carinae are present also on the last base; one is just at the rim of the umbilicus. The early ribs become unequally thinner and denser from the beginning of the fourth whorl; these sharp riblets remain the transverse ornament of the succeeding whorls and the base. The growth lines are fine but sometimes as marked as thin threads, which are much weaker and denser than the riblets.

Remarks - Comparable species from Bathonian strata is published by Cossmann (1885) as Turbo planispira (1885, p. 262, Pl. VII, figs 43-46). Fischer (1969) designated it as the type species for genus Planiturbo. The specimens from Ler are similar to the type species but the differences support their new species status: the early, markedly ribbed whorl part, following the planispiral portion, is lacking from the type species just like the thin riblets on the subsequent whorls and the base of Planiturbo lerensis $\mathrm{n}$. sp. The nodules of $P$. lerensis are much smaller on the base than in P. planispira and this seems to be true also for the nodes of the whorls that are poorly preserved.

Occurrence - Ler, upper Chari Formation, Callovian.

Subclass Caenogastropoda Cox, 1959

Superfamily Cerithioidea Fleming, 1822

Family CRYPTAULACIDAE Gründel, 1976

Subfamily Exelissinae Guzhov, 2004

Genus Exelissa Piette, 1860

Type species - Cerithium strangulatum d' Archiac, 1843

Exelissa indiana n. sp.

(Figures 29-45.)

Type speciumens - Holotype : Inv. №, BHU2020I 13; paratypes - Inv. №-s. BHU2020I 14-20.

Type locality - Khadir Island near Gadhada village.

Type strata - Gadhada Formation, Lower Callovian.

Name - Modified from India. 
Diagnosis - Small shells of turriculate spire with just detectible cyrtoconoidal outline. Full grown shells consisting of 9 to 12 whorls, separated by furrow of V-shape cross-section with suture in the deepest line. Outer face of whorls flattish between two sutural furrows. Last whorl downward and leftward tending, last peristome subcircular, trumpet-like. Ornament composed of sparse, collabral riblets and dense, differently strong spiral threads. Shell shape and ornament highly variable.

Material - 278 more or less incomplete specimens in addition to the types below (Inv. № BHU2020I 21- BHU2020I 299).

Measurements $-\mathrm{BHU} 2020 \mathrm{I} 13 \mathrm{HT}: \mathrm{H}$ dam. $=7.7 \mathrm{~mm}, \mathrm{D}=2.2 \mathrm{~mm}$ (Figures 29-31.); BHU2020I 14 PT1: $\mathrm{H}$ dam. $=9.8 \mathrm{~mm}, \mathrm{D}=2.7 \mathrm{~mm}$ (Figures 34-35.); BHU2020I 15 PT2: $\mathrm{H}$ dam. $=10.1 \mathrm{~mm}, \mathrm{D}=2.5 \mathrm{~mm}$ (Figures $42-44$.); BHU2020I 16 PT3: $\mathrm{H}$ dam. $=9 \mathrm{~mm}, \mathrm{D}=2.7 \mathrm{~mm}$ (Figures 40-41.); BHU2020I 17 PT4: $\mathrm{H}$ dam. $=9.5 \mathrm{~mm}, \mathrm{D}=2.5 \mathrm{~mm}$ (Figures 38-39.); BHU2020I 18 PT5: $\mathrm{H}$ dam. $=7.8 \mathrm{~mm}, \mathrm{D}=2.4 \mathrm{~mm}$ (Figures 32-33.); BHU2020I 19 PT6: $\mathrm{H}$ dam. $=7.5 \mathrm{~mm}, \mathrm{D}=2.1 \mathrm{~mm}$ (Figures $36-37$.); BHU2020I 20 PT7: $\mathrm{D}=2.4 \mathrm{~mm}$ (Figure 45.).

Description - Shells are rather highly turriculate with slightly pupiform outline. The teleoconch whorls are separated by deeply impressed suture, running in V-shaped furrow with angular rims. The wide outer face between the angulations is barely convex to barely concave. Base as a whole is convex with just convex wall; it joins to the outer face through the lower angulation that becomes rounded for the last whorl. The former coiling mode changing during formation of the last whorl; growing turns downward while the sutural furrow widens. The peristome, which is sub-quadrangular in earlier growth phases, changes into subcircular and its plane turns abaxially about $70^{\circ}$ from the former position beside increasing in its prosocline orientation. In its final form, the peristome is trumpet-like, and far extending left from the axis. The latest parietal and columellar lips are most commonly detached from the basal shell parts.

The shape of the growth lines is variably opisthocyrt between the almost straight to clearly arched degrees; their orientation is also changing between slightly prosocline to slightly opisthocline. This variability appears mainly between different specimens but sometimes also between whorls of a single specimen. The last whorl modifications result every time in marked prosocline growth line orientation. The teleoconch whorls are ornamented by sparse collabral ribs and differently strong spiral threads. Following the apparently smooth protoconch, not found in entire form, the ornament starts with single threads on angulations, which limit the outer face; they are crossed by few (7-8) riblets/whorl; third spiral thread appears on the next whorl between the former ones. The number of the spiral threads increase for the last whorl to ten or little more; the number of the ribs on the same whorl reaches $12 \pm 1-2$. The two primary threads, running on the angulations, become cord during the growth; the other threads remain thinner but variable in strength. The base is covered only with spiral threads. The ribs are 
nodose at intersections with the primary threads/cords and sometimes also at the other threads. Frequently, the ribs are rudimentarily developed but in a highly variable way: like nodes only at rims of the outer face, as shallow undulation, or fully lacking from shell parts, etc.

Remarks - In distinction of the early cerithiiform genera, key importance has been attributed to the morphology of the protoconch. Amongst the available abundant specimens, no entire early shell has been found. However, the observable earliest whorl, which may be part of the protoconch, is bicarinate in several specimens. By GuzHOv (2004) modified diagnosis, the last protoconch whorls in Exelissa are bicarinate. Since the shape of the teleoconch also corresponds to this genus, the Indian species is regarded also as Exelissa, in spite of the spiral ornament that has been said characteristically sparser.

The most similar species is the questionably Bajocian Exelissa africana Cox, 1965; its description (Cox 1965: p. 157) matches well also to this new Indian species; their close phylogenetical relation is probable. The most prominent differences are in their shape: Exelissa indiana n. sp. has more turriculate shell with only slight trace of cyrtoconoidal coiling while, at least in the holotype, $E$. africana has marked, cyrtoconoidally coiled early shell that gives bullet-like outline for the shell. Specimens, similar to the figured paratypes of $E$. africana do not occur in the Kachchh material. The shape and measurements of Exelissa (?) preralpina Cossmann, 1905 as figured by Cossmann (1913: p. 120, Pl. 5: 15-16) are similar to those of Exelissa indiana but differ in having a third marked and nodosed cord in mid-whorl position.

Occurrence - Khadir Island, Gadhada Formation, Lower Callovian.

Subclass Heterobranchia Gray, 1840

Superfamily Actaeonoidea d'Orbigny, 1843

Family APLUSTRIDAE Gray, 1847 (= Bullinidae Gray, 1850)

Genus Sulcoactaeon Cossmann, 1895

Type species - Actaeonina striatosulcata Zittel \& Goubert, 1861

\section{Sulcoactaeon? haboensis n. sp.}

(Figures 46-49.)

Type specimen - Holotype Inv. № BHU2020I 310.

Type locality - Habo Dome.

Type strata - Patcham Formation, Bathonian.

Derivation of name - Refers to the type locality.

Diagnosis - Bulliniform shell with single visible whorl of coaxial protoconch, and teleoconch whorls, having narrow, concave, subsutural ramp 
with sharp rim. Aperture elongated, leftward extending beyond axis in basal region. Peristome interrupted but thin inductura smoothen parietal wall. Outer and basal lip outward tapering. Columellar/umbilical lip arched and externally sharply angular; its widened inner surface hidden in normal apertural view since nearly perpendicular to plane of peristome. Hidden part having median furrow, possibly containing also narrow opening of umbilicus at its adapical end. Whole teleoconch, excepting ramp, ornamented by sparse spiral striae with ribbons in interspaces; few differently strong threads occurring along and on external part of columellar/umbilical lip.

Material - Single rather well-preserved specimen.

Measurements - Inv. №. BHU2020I 310: $\mathrm{H}=5.5 \mathrm{~mm}, \mathrm{D}=3.1 \mathrm{~mm}$.

Description - A minute, ovate shell of 4.5 visible whorls with impressed suture represents this species. The first whorl, which that is almost planispiral, convex and seemingly smooth, yet belongs to the protoconch, which is apparently coaxial with the teleoconch. A marked growth line indicates beginning of the teleoconch, which has a narrow, slightly concave ramp with a clear angulation as abaxial rim. The convex outer face of the whorls turns into the convex base without boundary. The peristome and aperture are subaxially elongated and extend higher than half of the full shell and have left side concave water drop shape. The outer lip is thin, outward tapering and smoothly arched to the basal lip, which continues as a sharp outer rim of the columellar/umbilical lip then terminates at the parietal wall. Major part of the columellar lip is hidden behind the sharp frontal edge; it is rather wide and nearly perpendicular to the plane of the peristome; in axial direction, it is slightly concave adaperturally, and has also a vertical furrow, perhaps with a narrow opening for a possible umbilicus. No trace of columellar or parietal folds is observable.

The first whorl, which belongs to the protoconch is smooth but, excepting the ramp, the teleoconch is sparsely striated along its full length; the striae separate nearly equally wide ribbons. Other ornament appears only on and along the outer rim of the columellar/umbilical lip as differently strong spiral threads of inequal length. The growth lines have nearly orthocline orientation and asymmetrically prosocyrt shape; near the ramp, their arch is narrower than elsewhere. Growth lines of the ramp are opisthocline and opisthocyrt.

Remarks - The striae of the shell are filled by unremovable sediment. However, short rim pieces of the ribbons show subregular undulations that may indicate pitted nature of the striae.

The species of Sulcoactaeon have frontally exposed columellar or umbilical lip and in this feature, they differ from the Kachchh specimen that has a new type of inner lip. It remains a question whether this inner lip bears only species or even generic level distinctive meaning; that is why the question mark is added to the genus name.

Occurrence - Habo Dome, Patcham Formation, Bathonian. 

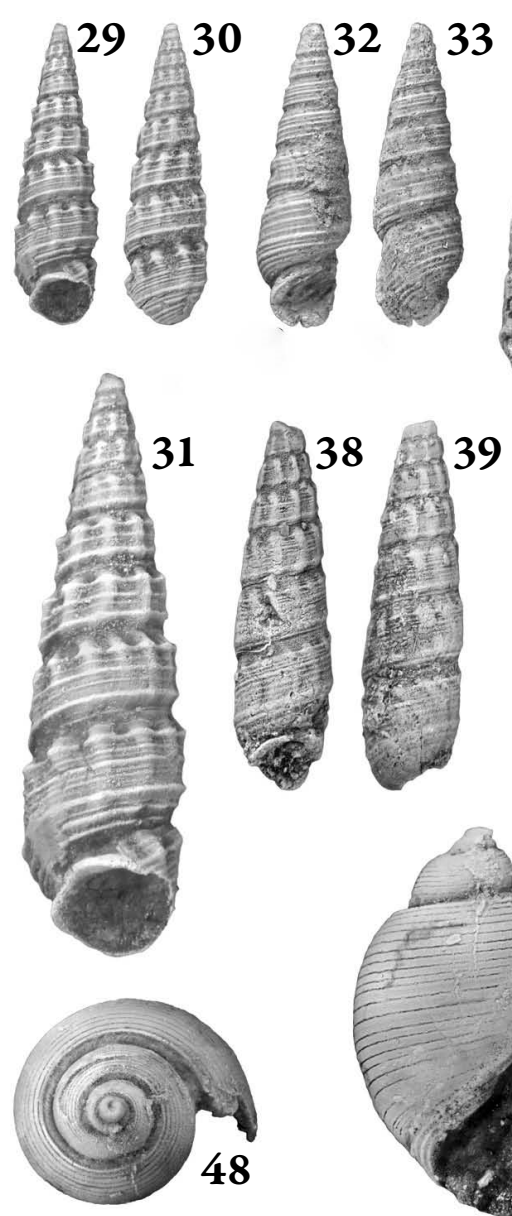
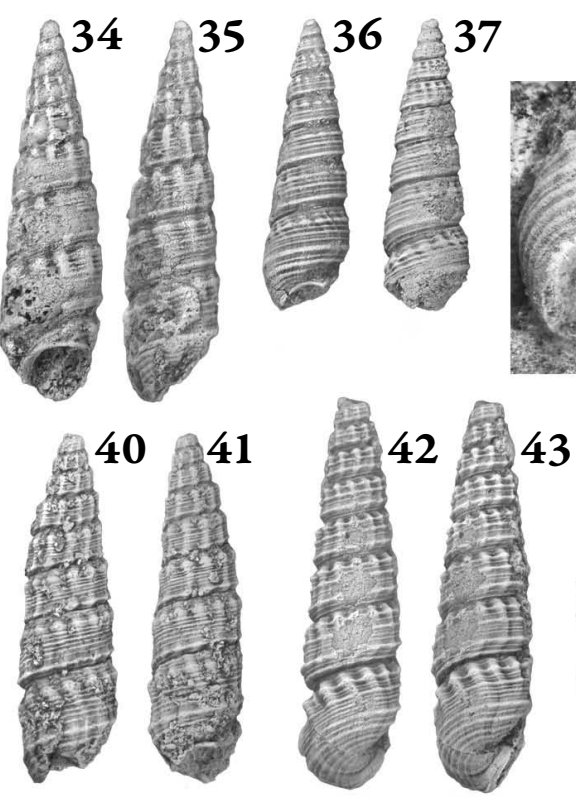

44
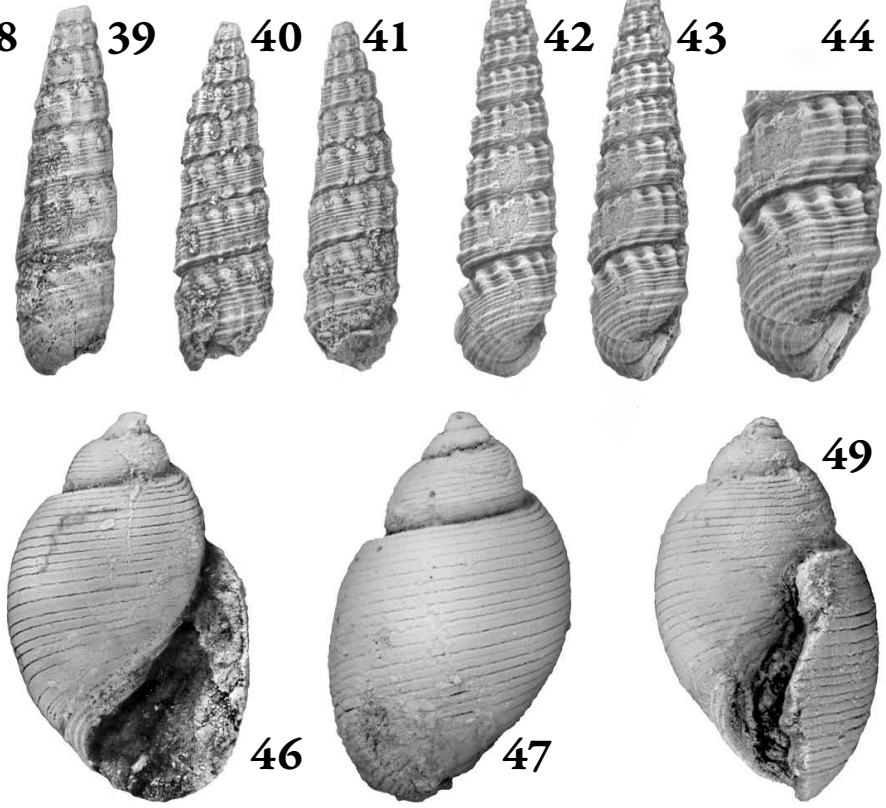

Figures 29-49. Caenogastropoda and Heterobranchia. 29-45 = Exelissa indiana n. sp. Holotype in apertural (29), and in abapertural (30) views, $\times 4$; ornament details of the holotype (31) in $\times 7.8$ magnification. The holotype in Figures 29-30. and six paratypes (BHU2020I 14-19) in Figures 32-43. are equally magnified $(\times 4)$ to demonstrate the high size, shape and ornament variability among the full-grown shells. The photo in Figure 44 (BHU2020I 19) is taken parallel to the most frequent final peristome plane, $\times 6$. Figure 45 is a perpendicular view to the plane of the trumpet like peristome, $\times 6.2$. Detailed data between the figures, the measurements, and the inventory numbers of the types are supplied above, in the species description. 46-49 = Sulcoacteon? haboensis n. sp., holotype in apertural (46), abapertural (47) and apical (48) views; oblique apertural view (49) shows inner face of columellar lip, bearing also vertical fissure of umbilicus; Figure 46 shows outline of the entire, very thin outer lip and the shape of the aperture. This outer lip suffered subsequently damages (49) during the cleaning of the inner lip region, bearing also diagnostic characters; all at $\times 7.3$ magnification. 


\section{SUMMARY}

In spite of the not really abundant and well-preserved material on hand, this paper can contribute to the knowledge of the Jurassic faunas of Kachchh with new data in a broad scale of Gastropoda (Vetigastropoda, Neritimorpha, Caenogastropoda, and Heterobranchia). Perhaps the most important information is connected to Cerithioidea since no former paper on the Jurassic faunas of Kachchh contains taxonomical details of this group. On lower taxonomical levels, presence of Jumaramaria n. gen. is remarkable since its morphological features are unique in all families of Pleurotomariina. Jumaramaria belongs to those few genera, which do not occur in the much more deeply studied "stable" European, neither in the Mediterranean/Inner Tethyan Jurassic faunas.

Acknowledgements - The studied gastropods were collected during lots of field trips mainly in the period between 1989 and 1999. We are thankful to the participants who are collectors of many specimens that are objects of this paper: M. Aberhan (Berlin), J. H. Callomon (London), F. T. Fürsich, M Heinze, S. Schlirf, M. Schlirf (Würzburg), W. Oschmann (Frankfurt), D. K. Pandey (Jaipur), and I. B. Singh (Lucknow). We thank also to Mr. B. H. Bhatti (Bhuj) for the helps to realization of these field works. Many thanks to A. V. Guzhov (Moskva) and to B. Erdei (Budapest) for the thorough review of the manuscript.

\section{REFERENCES}

Cossmann M. 1885: Contribution à l'étude de la faune de l'étage bathonien en France (Gastropodes). - Mémoires de la Société Géologique de France [3], 3(3): 1-374.

Cossmann M. 1913: Contribution a la Paléontologie francaise des Terrains jurassiques. III. Cerithiacea et Loxonematacea. - Mémoires de la Société Geologique de France, 19(3-4): 1-88, Pls 1-4.

Cox L. R. 1965: Jurassic Bivalvia and Gastropoda from Tanganyika and Kenya. - Bulletin of the British Museum (National History), Geology, Supplements 1: 1-213.

Fischer J.-C. 1969: Géologie, paléontologie et paléoécologie du Bathonian au Sud-Ouest du Massif Ardennais. - Mémoires du Muséum national d'Histoire naturelle, [C], 20: 1-319, pls $1-21$.

GuzHOv A. V. 2004: Jurassic gastropods of European Russia (orders cerithiiformes, bucciniformes, and epitoniiformes). - Palaeontological Journal, 38: 457-562, Suppl. 5.

International Commission on Zoological Nomenclature 1999: International Code of Zoological Nomenclature, Fourth Edition: adopted by the International Union of Biological Sciences. International Trust for Zoological Nomenclature, Padova, XXIX + $126 \mathrm{pp}$. 
JAitly A. K., Szabó J. \& Fürsich F. T. 2000: Contributions to the Jurassic of Kachchh, western India. VII. The gastropod fauna. Part I. Pleurotomarioidea, Fissurelloidea, Trochoidea and Eucycloidea. - Beringeria 27: 31-61, 3 text-figs, 6 pls.

Knight J. B., Cox L. R., Keen A. M., Smith A. G., Batten R. L., Yochelson E. L., Ludbrook N. H., Robertson R., Yonge C. M. \& Moore R. C. 1960: Mollusca - General features, Scaphopoda, Amphineura, Monoplacophora, Gastropoda - General features, Archaeogastropoda and some (mainly Paleozoic) Caenogastropoda and Opisthobranchia In: Moore R. C. \& Pitrat C. W. (eds): Treatise on Invertebrate Paleontology, Part I, Mollusca 1. - The University of Kansas Press, Lawrence, XXIII+351 pp.

Szabó J. \& JAitly A. K. 2019: Additional Middle Jurassic gastropods from Kachchh (western India) in the collections of the Banaras Hindu University (Varanasi, India) - Fragmenta Palaeontologica Hungarica, 36: 3-30. https://doi.org/10.17111/FragmPalHung.2019.36.3

\title{
Új csiga taxonok Kachchh (India) középső jurájából a Banaras Hindu Egyetem (Varanasi, India) gyüjteményében
}

\author{
SZABÓ JÁNOS ${ }^{1} \&$ ANAND KUMAR JAITLY ${ }^{2}$ \\ ${ }^{1}$ Magyar Természettudományi Múzeum, Öslénytani és Földtani Tár, \\ 1083 Budapest, Ludovika tér 2., Magyarország \\ E-mail:szabo.janos@nhmus.hu \\ ${ }^{2}$ Banaras Hindu University, Department of Geology, Varanasi-221005, India \\ E-mail:akjaitly@gmail.com
}

\begin{abstract}
Összefoglaló - Ez a cikk egy új genuszt és hat új fajt mutat be: Jumaramaria jumaraensis n. gen. \& n. sp. (Pleurotomariidae), Solarioconulus kachchhensis n. sp. (Ataphridae), Chartronella belaensis n. sp. (Paraturbinidae), Planiturbo lerensis n. sp. (Metriomphalidae), Exelissa indiana n. sp. (Cryptaulacidae) és Sulcoactaeon? haboensis n. sp. (Aplustridae). 49 ábrával.
\end{abstract}

Kulcszavak - Középső jura, India, Kachchh, Gastropoda, Jumaramaria 


\section{ÁBRAMAGYARÁZATOK}

1-16. ábra: Vetigastropoda, 1. 1-6 = Jumaramaria jumaraensis n. gen. n. sp.; a holotípus apikális (1), bazális (2), abaperturális (3), és apertura (4) nézetben, $\times 1,4$; (5) a rámpa részletei erősebb nagyításban, $\times 2,5 ;(6)$ a résszalag díszítésének részletei, $\times 4,4.7-11=$ Solarioconulus kachchhensis n. sp.; a holotípus abaperturális (7), apikális (8), aperturális (9) és bazális (10) nézetben, $\times 2$; az utolsó kanyarulat fúrásnyom-rendszerének felnagyított képe, $\times 3$. 12-16 = Chartronella belaensis $n$. sp.; a holotípus abaperturális (12), aperturális (13), apikális (14) és bazális (15) nézete, $\times 3,4$; (16) a spiralis díszítés maradványait hordozó héjdarab részletei, $\times 11$.

17-28. ábra: Vetigastropoda, 2. 17-23 = Planiturbo lerensis n. sp.; a holotípus aperturális (17), apikális (18), bazalis (19) és abaperturális (20) nézetben, $\times 2,8$; a korai ház részletgazdag nagyításban (21), $\times 9$; a bázis díszítésének a részletei (22), ×7,6; az utolsó kanyarulat díszítésének a részletei (23), $\times 7 . \mathbf{2 4 - 2 8}=$ Planiturbo lerensis n. sp.; a paratípus abaperturális (24), aperturális (25), bazalis (26) és apikális (27) nézetben $(\times 2,8)$, a legkorábbi kanyarulatok részletei $(28), \times 10,3$.

29-49. ábra: Caenogastropoda és Heterobranchia. 29-45 = Exelissa indiana n. sp.; a holotípus aperturális (29), és abaperturalis (30) nézetben, $\times 4$; a holotípus díszítésének a részletei (31) $\times 7,8$ nagyításban. A holotípus 29-30-as ábrái és hat paratipusnak (BHU2020I 14-19) az ábrái (32-43) azonos nagyításúak ( $\times 4)$, hogy szemléltessék a teljesen kifejlett házak méret-, alak- és díszítésbeli változatosságát. A 44. ábra felvétele (BHU2020I 19) a leggyakoribb utolsó peristoma sík helyzetének bemutatására készült, $\times 6$. A 45. ábra a trombitaszerü peristoma síkjára merőleges felvétellel készült, $\times 6,2$. A típusok méretei, leltári számai és ábrái közötti részletes kapcsolatok a fajleírásban találhatók meg. 46-49= Sulcoacteon? haboensis n. sp.; a holotípus aperturális (46), abaperturális (47) és apikális (48) nézete. Ferde aperturális nézet (49) mutatja be a columellaris ajak belső felületét, amely a köldök nyílását is hordozza. A 46. kép a nagyon vékony, még ép külső ajkat és az apertura formáját ábrázolja. A külső ajkat a felvétel készítését követően sérülések érték (49) a belső ajak diagnosztikus bélyegeinek feltárása során; valamennyi ábra nagyítása: ×7,3 . 